\title{
RAJOJA JA SÄRÖJÄ: \\ Talous maahanmuuttovastaisessa keskustelussa
}

\section{Katariina Mäkinen}

\begin{abstract}
Abstrakti
Artikkeli tarkastelee talouden poliittisuutta ja talouteen liittyvien kysymysten politisointia maahanmuuttovastaisessa keskustelussa. Tutkimusaineisto koostuu Hommaforumin (hommaforum.org) keskusteluketjuista. Analyysissa foorumin keskusteluista erottuu kolme erilaista tapaa puhua taloudesta: köyhyys siirtolaisten syynä, talousromahduksen odotus ja hyödyttömyys vastaan kunniallisuus. Puhetavat eroavat toisistaan, mutta kaikissa on viime kädessä kyse taloudellisen rationaliteetin sanelemista rajanvedoista, joissa henkilöiden tai ryhmien oletettu hyödyllisyys tai hyödyttömyys määrittää heidän paikkansa nationalistisessa projektissa eli siinä, millä tavoin Suomea keskusteluissa pyritään rakentamaan ja hallitsemaan.

Kahdessa ensimmäisessä puhetavassa taloudellinen rationaliteetti yhdistyy saumattomasti erilaisiin rodullistettuihin ja sukupuolitettuihin kategorioihin perustuviin moraalisiin arvostelmiin, kun taas kolmannessa puhetavassa näihin rodullistettuihin ja sukupuolitettuihin kategorioihin perustuva rajanveto säröilee ja syytökset moraalittomuudesta ja hyödyttömyydestä kohdistuvat paitsi maahanmuuttajïn myös kanssakeskustelijoihin. Johtopäätöksenä on, että maahanmuuttovastaisen keskustelun implisiittisenä järjestäjänä toimiva taloudellinen rationaliteetti toisaalta pönkittää siirtolaisuuteen liittyviä erontekoja ja tukee pyrkimyksiä nationalistiseen hallintaan, mutta saattaa johtaa myös nationalistisen oikeutuksen kyseenalaistumiseen niiden kohdalla, jotka eivät valkoisuudestaan ja "kantasuomalaisuudestaan" huolimatta onnistu tavoittamaan uusliberalistista ihannetta eli olemaan riittävän hyödyllisiä ja riippumattomia yksilöitä.
\end{abstract}




\section{Johdanto}

Tässä artikkelissa tutkin talouden poliittisuutta ja talouteen liittyvien kysymysten politisointia maahanmuuttovastaisessa keskustelussa. Tarkasteluni kohteena on internet-keskustelujen areenana toimiva Hommaforum (hommaforum.org). Kysyn, miten foorumin keskusteluissa puhutaan taloudesta ja miten nämä talouspuheen muodot kytkeytyvät laajempiin yhteiskunnallisiin konteksteihin. Artikkelin kysymyksenasettelu liittyy meneillään olevaan tutkimukseeni, jossa kehittelen erityisesti luokkaan ja talouteen keskittyvää näkökulmaa maahanmuuttovastaisen keskustelun tutkimiseen.

Maahanmuuttovastaisella keskustelulla tarkoitan poliittista keskustelua ja liikehdintää, joka murtautui Suomessa valtavirtaan vuoden 2008 kunnallisvaalien ja vuoden 2009 eurovaalien myötä (Keskinen 2009; Maasilta 2012a, 8-9) ja kulminoitui vuoden 2011 eduskuntavaaleihin ja Perussuomalaisten nousuun kolmanneksi suurimmaksi puolueeksi. Maahanmuuttovastaisuus ja rasismi eivät tietenkään sinänsä olleet mitään uutta suomalaisessa politiikassa (Förbom 2010), mutta keskustelun murros oli silti selvästi havaittavissa ja näkyi erityisesti uusien antagonismien eli vastakkainasettelujen nousussa politiikan agendalle (Maasilta 2012a, 8; Keskinen 2013a).

Suomalaisen poliittisen keskustelun muutos asettuu samaan jatkumoon kuin vastaavat murrokset muissa Pohjoismaissa ja Euroopassa 1990- ja 2000-luvuilla (Atton 2006: 573-574). Samaan tapaan kuin esimerkiksi Britanniassa (Atton 2006, 574), maahanmuuttovastaisen nationalistisen politiikan murtautuminen valtavirtaan on Suomessakin kytkeytynyt internetaktivismin nousuun ja netissä tapahtuvan toiminnan hyödyntämiseen (Lentin \& Titley 2011, 152). Olenkin kiinnostunut nimenomaan maahanmuuttovastaiseen politiikkaan liittyvästä ruohonjuuritason nettiaktivismista, jota Hommaforum vilkkaana keskustelufoorumina hyvin edustaa.

Internetaktivismi yhdistyy muuhun yhteiskunnalliseen keskusteluun kahdella tavalla. Yhtäältä nettikeskustelu liittyy suoraan puoluepolitiikkaan, sillä netissä organisoidutaan, kampanjoidaan, levitetään omaa puoluetta koskevaa tietoa ja pyritään vaikuttamaan puolueiden linjauksiin. Toisaalta keskustelu vaikuttaa julkiseen diskurssiin (Lentin \& Titley 2011, 151), joka ei ole palautettavissa ainoastaan puoluepolitiikkaan. Kyse on paitsi puolueiden ohjelmista myös siitä, millaiset näkökulmat saavat tilaa mediassa ja 
millaisia kannanottoja hyväksytään ja pidetään normaaleina (Lentin \& Titley 2011, 152).

Nettikeskustelun yhteys julkiseen diskurssiin ilmenee myös Hommaforumin äänenlausutussa strategiassa, jonka yksi moderaattoreista eli keskustelun valvojista tiivistää seuraavasti: "Homman missio on normalisoida sosiaalisen maahanmuuton kritiikki poliittisena kantana" (nimimerkki junakohtaus, 18.9.2013, 12:16:08, Poliisi otti yhteyttä Homma-kirjoituksesta). Tässä tavoitteessaan foorumin aktivistit ovat myös onnistuneet, sillä maahanmuuttokeskustelun murroksen jälkeen valtajulkisuudessa on annettu uudella tavalla tilaa ääriliikkeiden edustajille ja maahanmuuttopolitiikan suorasanaiselle arvostelulle (Maasilta 2012b, 161).

Alana Lentin ja Gavan Titley (2011, 21; myös Keskinen 2012, 287) kirjoittavat monikulttuurisuuden ja rasismin "toistetuista totuuksista" viitaten Michel De Certeau'n käsitteeseen (recited truths). De Certeau'n mukaan yhteiskunnallisia totuuksia tuotetaan kertomuksellisuuden ja toiston kautta. Toiston tuloksena "totuudet" näyttäytyvät annettuina ja itsestään selvinä, ja niiden alkuperä häviää näkyvistä. Hommaforum on yksi niistä paikoista tai areenoista, joissa maahanmuuttoon liittyviä totuuksia Suomessa tuotetaan ja joissa niistä kiistellään ja neuvotellaan. Näiden totuuksien merkitys rakentuu paitsi foorumin sisällä, myös ja erityisesti siinä, miten foorumilla tuotetut ilmaisut, näkemykset ja argumentit toistuvat eri tiedotusvälineissä ja siirtyvät siten osaksi poliittista "arkijärkeä". Hommaforum sisäisine ristiriitoineenkin on siis osa prosessia, jossa määritellään millainen puhe on ymmärrettävää ja hyväksyttyä, ja mikä nähdään totena.

Foorumin keskustelijat kutsuvat itseään "maahanmuuttokriittisiksi". Kriittisyys sanana ei nähdäkseni kuitenkaan anna kattavaa kuvaa keskustelun luonteesta, vaan on pikemminkin esimerkki maahanmuuttovastaisille ja nationalistisille poliittisille liikkeille tyypillisestä kielipoliittisesta pelistä eli tietoisesta kielellisestä strategiasta jossa sekä kehitellään uusia sanoja että annetaan vanhoille sanoille uusia merkityksiä (Koivulaakso ym. 2012, 59-61). Sanojen haltuunotto ja luominen on osa laajempaa poliittista strategiaa, jota Suvi Keskinen (2012) nimittää käänteisyyden politiikaksi. Kyse on retoriikasta, joka muuntelee ja ottaa valikoivasti käyttöön liberalistisen, antirasistisen, vasemmistolaisen ja feministisen ajattelun lähtökohtia ja kääntää ne tukemaan nationalistisia ja rodullistavia tavoitteita. Tällainen retoriikka aiheuttaa usein epätietoisuutta muissa poliittisissa toimijoissa, 
sillä yleisesti hyväksyttyjen sanojen ja lähtökohtien takaa on vaikea nähdä minkälaisia tavoitteita "maahanmuuttokriittisellä" politiikalla oikeastaan on.

Maahanmuuttokriittisyyden sijaan puhun tässä artikkelissa "maahanmuuttovastaisuudesta", vaikka tämäkin on varsin puutteellinen sanayhdistelmä (Betz ja Johnson 2004, 318). Tarkoittamaani keskustelua ei niinkään yhdistä maahanmuuton vastustaminen sinänsä kuin pyrkimys hallita ja rajoittaa maahanmuuttoa etnisten, uskonnollisten ja kulttuuristen kategorioiden perusteella. Katson silti, että maahanmuuttovastainen sanana kertoo enemmän kuin maahanmuuttokriittinen - keskustelussa ei vastusteta aivan kaikkea mahanmuuttoa, mutta kyse on kuitenkin ennemmin aktiivisesta vastustamisesta ja pyrkimyksestä vaikuttaa maahanmuuttopolitiikkaan kuin etäisestä ja analyyttisestä kriittisyydestä.

\section{Hommaforum tutkimuskohteena}

Hommaforum (lyh. Homma) on merkittävin yksittäinen internetfoorumi mahanmuuttovastaiselle keskustelulle Suomessa. Foorumi kehittyi alun perin Jussi Halla-ahon Scripta-blogin vieraskirjasta, ja siirtyi nykyiselle alustalle ja nykyiseen muotoonsa vuoden 2008 joulukuussa. Halla-ahon vuodesta 2003 toimineen blogin kirjoitukset käsittelevät lähinnä "monikultturismin" toimimattomuutta, islamia, "integroitumattomia" siirtolaisia sekä dystooppisia visioita "Lännen" tulevaisuudesta (Keskinen 2013a), ja samat aiheet sekä vieraskirjassa aikoinaan kehitellyt käsitteet kuten "hyysäri", "mokutus" ja "suvaitsevaisto" (Koivulaakso ym. 2012, 115) hallitsevat pitkälti myös Hommaforumin keskusteluja. Foorumin perustamisessa merkittävä rooli oli Halla-ahon blogin lisäksi Suomen Sisu -nimisen kansallismielisen järjestön sisällä toimineella ryhmällä, joka on 2000-luvun puolivälistä alkaen suunnannut toimintaansa yhä enemmän puoluepolitiikkaan (Koivulaakso ym. 2012, 117). Vilkkain ja merkityksekkäin aika Hommaforumin toiminnassa ajoittunee alkuaikoihin eli vuosiin 2009-2011 (taustahaastattelu 2) mutta yhä edelleen foorumilla on omien tilastojensa mukaan yli 8000 rekisteröitynyttä jäsentä, ja tänäkin vuonna (2013) uusia jäseniä on rekisteröitynyt yli 500 (Tilastot 23.9.2013). Viisi kuudesosaa sukupuolensa ilmoittaneista rekisteröityneistä käyttäjistä on miehiä.

Vaikka foorumin äänekkäin kirjoittajajoukko saattaakin suuresta 
jäsenmäärästä huolimatta olla suhteellisen pieni ja rajoittua muutamaan sataan innokkaaseen kirjoittajaan (taustahaastattelu 2), tämän artikkelin kirjoittamishetkellä (syyskuu 2013) foorumille kirjoitettujen viestien määrä on joka tapauksessa varsin suuri: 1330411 yksittäistä viestiä ja 35 988 aihetta (Tilastot 23.9.2013). Tutkimuksen näkökulmasta foorumin nykyinen sisältö muodostaa valtaisan tekstimassan, jonka lukeminen saati analyyttinen läpikäyminen ei yhdelle tutkijalle ole mahdollista. Kyse on enimmäkseen teksteistä, sillä kuvat (lukuun ottamatta käyttäjien avatarkuvia) ja videot ovat tutkimissani keskusteluissa suhteellisen harvinaisia. Lisäksi Hommaforumilla - kuten nettifoorumeilla yleensä - vallitsee oma keskustelukulttuurinsa jossa esimerkiksi sisäpiirin sanonnoilla ja ironialla on paljon merkitystä. Näistä syistä hyödynnän tutkimuksessani paitsi tekstianalyyttista myös etnografista tutkimusotetta. Tämä tarkoittaa, että olen tehnyt jatkuvaa "kenttätyötä" foorumin eri keskustelualueita lukien ja pyrkinyt ymmärtämään sekä keskustelukulttuuria että vallitsevia ymmärryksen ja toiminnan tapoja sekä sitä, millaiset aiheet ja kysymykset herättävät eniten vastakaikua.

Internet on haastava tutkimusympäristö sekä metodologisten että eettisten kysymysten kannalta (Laaksonen ym. 2013, 21). Tutkimani keskustelufoorumi on jatkuvassa liikkeessä, sillä keskustelut rönsyilevät ja kasvavat päivittäin ja käyttäjien tavat hyödyntää foorumia elävät ja muuttuvat. Tutkimus on aina eräänlainen pysäytyskuva, eikä se siksi voi tavoittaa lopullista totuutta tai "viimeistä sanaa" Hommaforumista tai muista verkkoyhteisöistä. Tästä syystä tutkimusotteeni ei pyri foorumin hahmottamiseen suljettuna kokonaisuutena. Tietoisuus foorumin luonteesta avoimena ja muuttuvana keskusteluympäristönä on ohjannut tulkintojani siten, että huomioni on kiinnittynyt erityisesti keskustelujen sisäiseen moninaisuuteen ja ristiriitaisuuteen. Tällöin kysymys ei niinkään ole siitä, millaiset argumentit yhdistävät kaikkia Hommaforumin kirjoittajia ja keskusteluja, vaan siitä millaisia erilaisia ja keskenään ristiriitaisiakin näkökulmia keskustelut sisältävät.

En toistaiseksi ole rekisteröitynyt Hommaforumin käyttäjäksi. Tämä tarkoittaa, että en pääse lukemaan "Peräkammarin" keskusteluja, mikä tietenkin rajoittaa käsitystäni foorumista (ja sen kirjoittajista). Päätökseni jättää rekisteröitymättä liittyy meneillään olevan tutkimuksen luonteeseen. Olen ensisijaisesti kiinnostunut foorumista julkisena keskusteluna, ja 
siksi en ole kokenut ongelmana analyysin rajoittumista vain kenen tahansa luettavissa oleviin keskusteluihin. Julkiset keskustelut ovat niitä tekstejä, joiden kautta Hommaforum toteuttaa poliittista tehtäväänsä normalisoida edustamansa näkemykset, joten ne ovat myös niitä tekstejä joiden kautta nähdäkseni parhaiten saa otteen siitä, millaisia nuo näkemykset ovat ja miten niitä perustellaan. Analyysin rajoittuminen vain julkiselle alueelle ei tuo mukanaan samanlaisia eettisiä ongelmia kuin rekisteröitymistä vaativan sisällön tutkiminen (Turtiainen \& Östman 2013, 59), ja siksi rekisteröitymisen toteuttaminen edellyttäisi erityisen painavia syitä, joita ei tähän asti ole tutkimuksessani tullut vastaan.

Etnografisen lähestymistavan tueksi olen tehnyt kolme foorumin nykyisten tai aiempien aktiivikirjoittajien taustahaastattelua. Haastattelut ovat käsitelleet lähinnä kirjoittajien näkemystä foorumin luonteesta, foorumilla suosituista aiheista, moderoinnista sekä foorumin kirjoittajia yhdistävistä tekijöistä ja foorumin poliittisesta merkityksestä ja tavoitteista. Käytän näitä haastatteluja tekstianalyysin tukemiseen ja taustoittamiseen soveltaen tarpeen mukaan myös lähdekriittisyyttä.

Kenttätyön johdattelemana (ja toki käytännössä samaan aikaan edelleen jatkuvan kenttätyön kanssa) olen muodostanut tutkimushypoteeseja ja valikoinut muutamia keskusteluketjuja lähemmän analyysin kohteeksi. Näitä keskusteluja luen "läheltä" eli hyödyntäen erilaisia tekstin tulkinnan metodeja (kertomuksen analyysi, intertekstuaalisuus, subjektipositioiden analyysi) ja keskusteluttaen tekstejä teoreettisen tutkimuskirjallisuuden kanssa.

Käsitykseni teorian paikasta tutkimuksessa on etnografisen lähestymistavan mukainen: ymmärrän tutkimuksen teoriaa luovana ja kehittävänä prosessina, joka muotoutuu sekä alhaalta ylöspäin painottaen tutkimuskohteen erityisyyttä että ylhäältä alaspäin yleisemmän teoreettisen tason tarkasteluna. Teoria suuntaa ja järjestää tutkimusta, ja tutkimuskohteen erityisyydestä nousevat haasteet ja ongelmat johdattavat arvioimaan uudelleen ja korjaamaan niitä yleisempiä näkökulmia, joihin tutkimuksessa tukeudutaan (Isomäki ym. 2013, 152-153).

Sekä yksittäisten ketjujen analyysia että koko tutkimushankettani ovat suunnanneet kriittinen monikulttuurisuuden, rasismin ja antirasismin tutkimus (Lentin \& Titley 2011; Pitcher, 2012; Hage 2003; 2000) sekä feministinen luokkatutkimus (Skeggs, 2004; 1997; Tyler 2008). 
Monikulttuurisuuden kriittinen tutkimus paikantaa maahanmuuttokeskustelua osaksi erityisellä logiikalla toimivaa nationalistista projektia (Hage 2000) ja valottaa tämän nationalistisen projektin laajuutta ja moniulotteisuutta, kun taas feministinen luokkatutkimus nostaa esiin valkoisuuden kytköksen kunniallisuuden ja vastuullisuuden ihanteisiin - ja niiden saavuttamattomuuteen.

Tässä artikkelissa kysymyksenasetteluni on ohjannut minut lähilukemaan erityisesti talouskriisiä, romanikerjäläisiä, köyhyyttä ja leipäjonoja sekä filippiiniläisiä siirtotyöläisiä koskevia keskusteluketjuja. Nostan esille kolme erilaista ja keskenään ristiriitaistakin tapaa, joilla taloudesta näissä keskusteluketjuissa puhutaan: köyhyys siirtolaisten syynä, talousromahduksen odotus ja kunniallisuus vastaan hyödyttömyys. ${ }^{1}$ Seuraavassa käyn läpi näitä eri talouspuheen muotoja sekä niihin liittyvää ymmärrystä paitsi taloudesta myös toisista ihmisistä ja yhteiskunnasta kokonaisuutena. Lopuksi kysyn, millaisia yhteisiä piirteitä eri talouspuheista voi tunnistaa ja mitä merkitystä näillä piirteillä on laajemman keskustelun kannalta.

\section{Köyhyys siirtolaisten syynä}

Kesäkuussa 2011 evankelis-luterilaisen kirkon piispa Mikko Heikka kirjoitti Suomen Kuvalehden nettisivuille blogimerkinnän otsikolla "Suomalaisia köyhiä ajetaan maahanmuuttajia vastaan". Lyhyehkössä kirjoituksessaan Heikka käsittee köyhyyttä ja oikeudenmukaista politiikkaa, ja toteaa että "poliittisessa retoriikassa esiintynyt mahanmuuttokriittisyys on vaalien jälkeen muuttunut arkipäivän rasismiksi. Maahanmuuttajat nähdään vihollisina, jotka syövät Suomen köyhien pöydästä”. Kirjoituksessaan Heikka kyseenalaistaa tämän käsityksen ja puolustaa erityisesti romanisiirtolaisten ihmisoikeuksia ja ihmisarvoa.

Hommaforumilla Mikko Heikan kirjoitusta kommentoitiin blogin otsikon mukaan nimetyssä keskusteluketjussa 2011-06-26 SK: Mikko Heikka: Suomalaisia köyhiä ajetaan maahanmuuttajia vastaan [Suomalaisia köyhiä] aikavälillä 26.6.2011-28.6.2011 28 viestin verran. Tätä keskustelua käytän seuraavaksi aineistona tutkiessani sitä, miten köyhyys, kerjääminen ja siirtolaisuus foorumilla ymmärretään. Suomalaisia köyhiä -ketju on lyhyt verrattuna moniin muihin foorumin keskusteluihin, mutta se on 
kiinnostava siksi, että Heikan esittämä väite "maahanmuuttajat nähdään vihollisina, jotka syövät Suomen köyhien pöydästä" osuu suoraan keskustelun ytimeen. Toisin sanoen keskustelu näyttää konkreettisesti sen, miten köyhyys ja rasismi kytkeytyvät - tai kytketään - toisiinsa maahanmuuttovastaisessa keskustelussa.

Suomalaisia köyhiä -keskusteluketjua hallitsee vastakkainasettelu "meidän" ja "muiden" välillä. Tässä kaikki keskusteluun osallistujat kuuluvat meihin, ja Suomeen saapuneet romanit sekä muut siirtolaiset muihin. Keskustelun pääasiallinen ja useissa muissakin yhteyksissä toisteltu sanoma on, että "meillä suomalaisilla" menee huonosti tai ainakin alkaa pian mennä huonosti, ja tämä on siirtolaisten syytä joko suoraan tai välillisesti. Siirtolaisten lisäksi syyllinen asioiden huonoon laitaan on myös "eliitti" (johon muun muassa evankelis-luterilainen kirkko kuuluu), sillä eliitti yrittää auttaa siirtolaisia ja samalla unohtaa "kantasuomalaiset", joiden etujen nähdään olevan sovittamattomalla tavalla vastakkain siirtolaisten etujen kanssa $^{2}$. Tätä sanomaa kaikessa yksinkertaisuudessaan voi pitää foorumilla vallitsevan maahanmuuttovastaisuuden keskeisenä ja kokoavana sisältönä, jonka täsmällinen ilmaisu vaihtelee asiayhteyksien ja puhujien mukaan. Köyhyyden ollessa puheena tämä näkemys tiivistyy esimerkiksi seuraavassa varsin katkeransävyisessä kommentissa:

Mitä useampi suomalainen asuu roskalaatikossa tai rappukäytävässä, sitä paremmin on työt hoidettu heidän mielestään, kunhan kunnon olot on muualta tulleilla ja tulevilla. (Nimimerkki Kitaransoittaja 28.6.2011, 17:53:22 Suomalaisia köyhiä).

Yllä oleva lainaus asettaa kysymyksen köyhien auttamisesta ja yhteiskunnallisen tilanteen korjaamisesta ("työt") sekä oikeudenmukaisuudesta mahanmuuttovastaiselle keskustelulle tyypilliseen kehykseen. Katkeruutta herättää oletus siitä, että "eliitti" ei tunnista "kantasuomalaisten" hätää tai välitä heidän ongelmistaan vaan suuntaa taloudelliset resurssinsa sekä myötätuntonsa siirtolaisten tukemiseen.

Kantasuomalaisten leipäjonon tarvitsijoiden ja muiden köyhien ja muuten vähätuloisten ihmisten kohdallahan ei ole kysymys ihmisoikeuksista ja ihmisarvosta (Nimimerkki jupeli 27.6.2011, 12:27:22 


\section{Suomalaisia köyhiä).}

Tämä tulkinta on sikäli erikoinen, että Heikan alkuperäinen kirjoitus ei suurelta osin keskity niinkään erityisesti siirtolaisten tilannetta parantaviin toimenpiteisiin vaan köyhyyteen yleisesti ja esimerkiksi perusturvan nostamiseen. Hommaforumin keskustelussa tämä osuus kirjoituksesta kuitenkin ohitetaan, ja eri keskustelijoiden puheenvuoroissa huomiota saa lähinnä kysymys siitä kuinka "mamuille" jaetaan "hövelisti verorahaa" (nimimerkki Jaska Pankkaaja 27.6.2011, 09:29:57 Suomalaisia köyhiä) kun taas "kantasuomalaiset" joutuvat asumaan "roskalaatikossa tai rappukäytävässä" (lainaus yllä). Vastakkainasettelu, jota Heikka kritisoi tarkoitushakuisuudesta ja keinotekoisuudesta, luetaan siis näin hänen omaan tekstiinsä.

Köyhyyttä käsittelevän keskustelun vastakkainasetteluun meidän ja muiden välillä sisältyy tietynlainen ymmärrys taloudesta. Yhteiskunnassa jaettavissa oleva varallisuus tai muu hyvä käsitetään muuttumattomana "kakkuna", josta riittää jaettavaa sen mukaan, montako ihmistä kakkua on jakamassa. Jaettavan hyvän määrä siis oletetaan vakioksi, ja kysymys nähdään olevan siitä, kenelle hyvää jaetaan ja kuinka paljon:

Mielenkiintoista. Kuvittelin kirjoittajan päätyvän siihen johtopäätökseen, että rasismia synnyttävät sekä lisääntyvä kakunjakajien määrä että se, kun kakusta ei riitä maiskutettavaa edes omille ovat köyhät vihaisia kun uudet tulijat vievät köyhälle kuuluvat muruset. (Nimimerkki Lady Delirium 26.6.2011, 23:55:30 Suomalaisia köyhiä).

Minusta, kun Suomeen kahmitaan tietentahtoen [sic] muiden maiden köyhiä kansalaisia jakamaan jo valmiiksi tarpeeksi täydestä köyhien tämän maan kansalaisten pöydästä, tulee tietynlainen törmäys. Se, että miten vitussa (anteeksi) ne - jo valmiiksi Suomen pöydässä olleet Suomen köyhät - nyt on ajettu pöydän ääreen tuputettuja maahanmuuttajia vastaan on minulle kyllä mysteeri. Minusta he osaavat tehdä sen jo itse huomaamalla että hei, tämä ei ole oikeudenmukaista, tämä ei toimi näin ja jos tämä porukan lappaaminen tähän pöytään jatkuu, ei pöydässä ole enää kohta kenellekään kunnollista paikkaa. (Nimimerkki DEVUSKA 26.6.2011, 23:31:26 Suomalaisia köyhiä). 
Pöytä- ja kakkumetaforat kuvaavat samaa asiaa eli lähtökohtaisesti tietyn suuruista hyvää, jota jaetaan. Samalla niihin sisältyy kyseenalaistamaton oletus siitä, että joillakin ("meillä") on jakamaton oikeus saada osamme kakusta ja paikka pöydän ääressä. Oikeudenmukaisuus siis on koetuksella silloin, kun "meidän" paikkamme ja kakkupalamme ovat uhattuina. Suomalaisia köyhiä -keskusteluketjussa tätä annettuna otettua oikeutta ei oikeastaan perustella mitenkään muuten kuin sillä, että "me" olemme täällä jo ("jo valmiiksi Suomen pöydässä olleet Suomen köyhät") ja että "me" olemme "tämän maan kansalaisia" emmekä "uusia tulijoita". Näin rakentuvassa nationalistisessa kehyksessä (Hage 2000, 32) kansalaisuus eli kuuluminen "meihin" siis näyttäytyy itsestään selvänä oikeutuksena päästä osalliseksi siitä hyvästä, mitä Suomen valtiona tai yhteiskuntana ajatellaan tuottavan, ja samalla tuon hyvän määrä ajatellaan muuttumattomana. Tällä tavoin taloudellisen vaurauden jakopolitiikka pelkistyy puheeksi maahanmuutosta, ja kysymys siitä millä tavalla ja keiden toimesta yhteistä hyvää tuotetaan ja miten sitä jaetaan muuten kuin maahanmuuttajien ja "kantasuomalaisten" välillä rajautuu kokonaan ulos keskustelusta.

Keskustelijoilla tulisi mielestään olla oikeus päästä osalliseksi "kakusta", mutta myös päättää siitä, keille kaikille "kakkua" jaetaan eli ketkä sen ovat ansainneet. Turhautumista ja tyytymättömyyttä näyttää herättävän nimenomaan se, että tosiasiallisesti päätösvalta ei ole omissa käsissä, vaan joku muu "kahmii" Suomeen "uusia tulijoita". Keskusteluketjussa rakentuva pyrkimys nationalistiseen hallintaan on siis nimenomaan pyrkimys, osittain kuvitteellinen ja toivottu suhde sekä omaan itseen että siihen Suomeen, jonka asioista keskustelussa ollaan kiinnostuneita (Hage 2000, 42-46).

Siinä missä "meidän" oikeuttamme yhteiseen hyvään tai siitä päättämiseen ei keskustelussa juurikaan perustella, "uusien tulijoiden" oikeudettomuutta rakennetaan paitsi kansalaisuuteen ja etnisyyteen myös näihin kytkettyyn moraalittomuuteen liittyvien mielikuvien ja rajanvetojen avulla. Romanisiirtolaiset, joihin ketjussa monesti viitataan, eivät ole keitä tahansa "muita", vaan he kuuluvat ryhmään, jonka uskotaan olevan moraalisesti alempiarvoinen. Tämä romaneja ja erityisesti romanikerjäläisiä koskeva "tieto" ei ole ainoastaan Hommaforumilla tuotettua, vaan tuttua monista muistakin yhteyksistä (kuten taannoin julkisuudessa käydystä kerjäämiskieltokeskustelusta) ja suorassa yhteydessä romanien historiaan Suomen vainottuna vähemmistönä ja koko Euroopan paariakansana (Nordberg 
2010, 257). Suomen romaneihin pitkään liitetyt rasistiset mielikuvat varastamisesta ja epärehellisyydestä ovat maahanmuuttokeskustelussa siirtyneet kuvaamaan myös romanisiirtolaisia. Näin moraalinen rappio liitetään tiettyyn "kulttuuriin" ja sen "edustajiin", jotka on mahdollista erottaa "meistä" jo ulkonäkönsä perusteella. Tämä on tyypillistä maahanmuuttoa koskevalle keskustelulle niin Hommaforumilla kuin koko Euroopassakin: rotu käsitteenä on toisen maailmansodan jälkeen korvattu puheella "kulttuureista", joilla nyt perustellaan hierarkioita ja valtasuhteita ikään kuin kyse ei edelleen olisi rasismista (Lentin ja Titley 2011, 49; Lentin 2005).

"Turvapaikkashoppailijan" ja "ankkurilapsen" tavoin myös romanikerjäläisen hahmo on viime vuosina muodostunut eräänlaiseksi ylimäärittyneeksi sosiaaliseksi karikatyyriksi, johon negatiiviset mielikuvat moraalittomuudesta tiivistyvät (vrt. Horsti 2005, 87). Romanikerjäläisiin ja erityisesti kerjäläisnaisiin liitetään käsityksiä paitsi epärehellisyydestä myös holtittomasta lisääntymisestä ja vastuuttomasta äitiydestä:

Katukuvassa ainakin täällä pk-seudulla ei ole harvinainen näky kerjäläisnainen (tuntikausia!) nukkuva / makaava lapsi sylissään - onko lapsi huumattu? Miten lapsi saadaan makaamaan lähes liikkumatta naisen sylissä tällä tavalla tuntien ja taas tuntien ajan? (Nimimerkki Brandöt 26.6.2011, 23:57:02 Suomalaisia köyhiä).

Imogen Tyler (2008) on tutkinut Britannian valkoista alaluokkaa kuvaavaa mediajulkisuutta ja erityisesti julkisuudessa yhä uudelleen esiintyvää moraalittoman "chav"-äidin hahmoa, jolla on historialliset juurensa työväenluokan naisiin jo 1800-luvulta saakka liitetyissä mielikuvissa (Skeggs 1997, 46). Tylerin mukaan "chav"-äidin kaltaiset demonisoidut karikatyyrit, joita kierrätetään eri julkisuuden alueilla niin politiikassa kuin viihteessäkin, kantavat yhteiskunnallista ja poliittista tehtävää: ne auttavat oikeuttamaan yhteiskunnallista eriarvoisuutta. Samankaltaista dynamiikkaa ja samankaltaisia määreitä kuten huonoa äitiyttä, liiallisuutta ja holtittomuutta voi tunnistaa myös romanikerjäläisen hahmon kohdalla: kerjäläisiin kohdistuva pelko, inho ja viha oikeutetaan kuvaamalla heidät moraalittomiksi sekä suhteessa omaisuuteen että suhteessa hyvän äitiyden ihanteisiin, ja samalla oikeutetaan myös ajatus siitä, että heille ei tarvitse yhteisestä kakusta jakaa tai varata paikkaa yhteiseen pöytään. Rodullistunut ja sukupuolittunut 
kuvasto palvelee vanhaa ajatusta ansaitsevista ja ansaitsemattomista köyhistä (Shildrick ja MacDonald 2013, 295; Skeggs 1997, 46) ja auttaa tekemään jakoa "meidän" ja "muiden" välillä.

\section{Talousromahduksen odotus}

Hommaforumin perustaminen tapahtui lähes yhtä aikaa Yhdysvaltojen vuoden 2008 talouskriisin kanssa, ja foorumilla onkin ahkerasti paneuduttu talous-, energia- ja ympäristökriisin analysointiin ja kriisiin liittyvien dystooppisten tulevaisuuskuvien maalailuun. Tätä puhetta olen tarkastellut erityisesti kahdessa ketjussa: Globaali taloustilanne/LAMA! (yhdistetty) [GTL] aikavälillä 25.2.2009-4.6.2013 (1355 viestiä) sekä Öljykriisi, talousrommaus ja energia-asiat (yhdistetty) [ÖTE] aikavälillä 7.8.2009-7.9.2013 (319 viestiä). Kumpikin ketju on talousasioita käsittelevällä Mylly-keskustelualueella, ja suuri osa ketjujen keskusteluista käsittelee varsin yksityiskohtaisesti erilaisia taloudellisia mekanismeja ja niiden suhdetta esimerkiksi libertaristisiin ihanteisiin sekä erilaisia spekulointeja taloustilanteen kehittymisestä, jolloin yhteys maahanmuuttovastaisuuteen jää usein implisiittiseksi. Ketjuja analysoidessani olenkin kiinnittänyt erityistä huomiota kohtiin, joissa keskustelijat liittävät talouskeskustelua suoraan monikulttuurisuus- ja maahanmuuttokysymyksiin.

Hommaforumin puheenvuoroissa usein toistuva näkemys on, että talouden romahdus on ensinnäkin väistämätöntä ja toiseksi siinä mielessä hyvä asia, että romahduksen tullessa muun väestön ja etenkin "eliitin" on pakko "tunnustaa tosiasiat" ja ryhtyä kovempiin toimiin maahanmuuton rajoittamiseksi:

[...] varmaankin oikaisen ja yksinkertaistan liikaa tässä, mutta joskus sekin on tarpeellista asioiden selkeyttämiseksi:

- Jos halpa öljy on mahdollistanut talouden globalisaation, sitten kallistuva öljy uhkaa globalisaation tulevaisuutta.

- Jos talouden globalisaatio on mahdollistanut monikulttuuriideologian, sitten globalisaation hiipuminen uhkaa monikulttuuriideologian tulevaisuutta.

- Jos monikulttuuri-ideologia on uhattuna, se tietää nuiville nostetta. (Nimimerkki Nikolas Ojala 19.2.2011, 15:01:04 GTL). 
[...] joo. Myös öljyhuippu saa aikaan globaalin laman, jolloin moku-sektorilta on sitten rahat loppu. Näinkin simppeliä se on. (Nimimerkki hattiwatti 18.3.2011, 14:13:57 GTL).

Jos suomalaiset torjuvat monikulttuurisuuden ja pitävät oman alueensa omassa hallinnassaan, heillä on hyvät mahdollisuudet jatkaa olemassaoloaan. Täällä on vettä, maata ja metsää (=energiaa). Mitä enemmän Suomeen tulee muita kansoja, sitä vähemmän Suomen resursseista riittää suomalaisille. Jokainen somali vie omalta osaltaan pois sitä elintasoa, jota Suomen alueen resurssit pystyvät tuottamaan suomalaisille. Tähän asti resursseista ei ole ollut kuolemanvakavaa kilpailua, kun öljyn globaalit tuotantomäärät ovat kasvaneet. Tulevaisuudessa on toisin. (Nimimerkki nyt nappaa 7.8.2009, 22:31:19 ÖTE).

Keskustelussa toistuu yhtäältä epäluottamus ja tyytymättömyys poliitikkojen tähänastiseen toimintaan ja toisaalta toive siitä, että talousromahduksen seurauksena tulee "uusjako" jossa yhteiskunnan päättäjät joko heräävät tai sitten kansalaisilla on "mahdollisuus ottaa ohjat uusiin käsiin" (nimimerkki samuliloov 28.8.2011, 00:12:29 GTL).

Erityistä vastenmielisyyttä keskusteluketjuissa kohdistuu pankkeihin ja pankkiireihin, joiden ahneutta pidetään syynä talousromahdukseen. Pankkiireilla nähdään myös olevan halua edesauttaa siirtolaisuutta ja siirtolaisten tukemiseen tähtääviä toimia, sillä heillä on motivaatio "sponsoroida kaikkea kallista ja matalatuottoista toimintaa, joka velkaannuttaa yhteiskunnat" (Lalli IsoTalo, 20.7.2011, 17:36: 16 GTL). Samoin monissa kommenteissa viitataan siihen, että monikulttuurinen ihanne toimisi verukkeena halpatyövoiman tuomiselle Suomeen ja olisi siksi kannattavaa "eliitille".

Toinen ketjussa esiintyvä tulkinta on, että Yhdysvaltojen talousromahdukseen oli syynä lainojen myöntäminen väärille henkilöille eli siirtolaisille tai neekereille (tätä rasistista ilmaisua Hommaforumilla pyritään virallisen politiikan mukaan välttelemään, mutta käytännössä se toistuu keskusteluissa aika ajoin).

Itse pidän aika selvänä, että nykyinen talouskriisi lähti idealistisesta tavoitteesta tehdä miljoonista siirtolaisista USAssa uusi keskiluokka, myöntämällä näille vastikkeettomia asunto- ja kulutusluottoja. (Nimimerkki 
Risto A. 8.3.2009, 10:39:02 GTL).

Käsittääkseni finanssikriisi ei johtunut vapaan markkinatalouden epäonnistumisesta, vaan kyse oli talouden sääntelystä, joka purkautui tietysti tällä tavoin. Hitto, ettei enää muista, miten, mutta muistaakseni Yhdysvaltain hallitus kielsi yhtiöitä tekemästä jotain ja tuki neekereiden roskalainoja talohankintoja varten, minkä seurauksena finanssikriisi syntyi. (Nimimerkki Advancedisto 3.7.2009, 15:53:18 GTL).

Suurena syynä tuolle oli myös tämänkin foorumin aihepiiriin liittyvä syy eli rasismi. Olisihan näet rasistista vaatia lainoja myönnettäessä maksukykyä, koska silloin mustat eivät saisi hankittua asuntoa. (Nimimerkki JNappula 4.7.2009, 20:06:28, GTL).

Yhdysvaltojen oletetun anti-rasistisen politiikan nähdään siis suoraan vaikuttaneen talouskriisin syntyyn. Samassa hengessä Suomen monikulttuurisen politiikan nähdään johtaneen "tuhlailuun", joka on pahentanut taloustilannetta ja jonka on nyt laman kynnyksellä loputtava:

Leikatkaa perkeleet, mutta leikkaatte ensin turvapaikanhakijoilta. Niiden sosiaaliturvasta ettekä ota vastaan enää yhtään ankkuria saatana ennen kuin on tämän maan talous saatu kuntoon. (Nimimerkki PethetePerkele 1.6.2009, 09:39:33 GTL).

Talousromahdus nähdään siis siinä valossa, että yhteistä "kakkua” on entistä vähemmän jaettavaksi, ja tällöin kustannustehokas ratkaisu on rajoittaa maahanmuuttoa ja siirtolaisten tukemiseen käytettäviä varoja entisestään:

Iilimadot ulos maasta imemästä kansan elinvoimaa, takaisin aavikolle. Mamu-bisnesmiehet kuten sisäministerin veli vaikka marjanpoimintaan, paljon hyödyllisempää kansakunnalle. (Nimimerkki nyt nappaa 1.6.2009, 18:15:13 GTL).

Vaikka Hommaforumin keskusteluissa poliitikkojen nähdään olevan kykenemättömiä maahanmuuttoa koskeviin "välttämättömiin" päätöksiin, on kuitenkin huomattava että foorumin puhetapa itse asiassa resonoi valtavirran 
poliittisen retoriikan kanssa. Esimerkiksi Suvi Keskinen (2013b) on todennut, kuinka maahanmuuttopoliittista retoriikkaa Suomessa hallitsee (lähes puolueesta riippumatta) taloudellinen rationaliteetti, jossa maahanmuuttopolitiikan tavoitteena on ensisijaisesti kilpailukyvyn kasvattaminen ja kustannusten hallinta. Keskisen mukaan Suomen maahanmuuttopolitiikka määrittyy eri puolueiden retoriikassa viime kädessä kysymykseksi siitä, "onko meillä varaa hyvinvointivaltioon" (Keskinen 2013b). Samankaltainen argumentointi hallitsee myös Hommaforumin keskustelua talouskriisistä ja maahanmuutosta: taloudellinen rationaliteetti määrittää suhdetta siirtolaisiin ja siirtolaisuuteen. Kysymys on nimenomaan siitä, mikä on "hyödyllistä kansakunnalle" (lainaus yllä). Monien kommenttien viesti on, että talouden lait tulevat itse asiassa sanelemaan Suomen maahanmuuttopolitiikan - riippumatta poliittisista toimijoista tai päätöksistä. Ainakin tässä suhteessa foorumin kirjoittajien poliittinen positio näyttäytyy lopulta hyvin yhteneväisenä "eliitin" position kanssa.

Talouskriisiä käsittelevässä keskustelussa on havaittavissa myös taloudellisen "realismin" ja naiiviuden vastakkainasettelua. Kuten edellä olleista lainauksista käy ilmi, korostettu rationaalisuus antaa foorumilla helposti tilaa hyvinkin emotionaalisille argumenteille ja puuskahduksille ("leikatkaa perkeleet"). Tästä huolimatta keskustelun yleisvire rakentuu niin, että foorumin kirjoittajilla on ikään kuin parempi ja rationaalisempi ymmärrys talouden realiteeteista verrattuna sekä maahanmuutosta vastuullisina pidettyihin poliitikkoihin (Astrid Thors) että Suomeen tuleviin siirtolaisiin.

Astridin mielestä valtion seinä on ehtymätön. (Nimimerkki Hessu 19.4.2009, 09:53:24 GTL)

Mutta rahaahan tehdään painokoneilla ja sitä saa sitten taikaseinästä Valden piikkiin. Vai miten se oikein meni. (Nimimerkki requiem 24.3.2010, 08:37:44 GTL).

Keskustelun "me" eli tarkkojen analyysien ja laskelmien rationaaliset laatijat asettuvat vastakkain niiden kanssa, jotka luulevat, että "rahat tulevat taikaseinästä". Tämä vastakkainasettelu liittyy laajempaan yhteiskunnalliseen kontekstiin eli uusliberalismiin, jossa vastakkain asettuvat rationaalinen, itseään hallitseva kansalainen ja riippuvainen, omapäinen ja resursseja 
kuluttava subjekti (Lentin ja Titley 2011, 178). Lisäksi realismia ja rationaalisuutta korostava puhetapa kytkeytyy populismille tyypilliseen "tavallisen kansan maalaisjärjen" korostamiseen suhteessa "poliittista korrektiutta" harjoittavaan "eliittiin" (Lentin ja Titley 2011, 113). Hommaforumin keskustelu näyttää konkreettisesti näiden näennäisesti neutraalien vastakkainasettelujen sukupuolittuneen ja rodullistetun luonteen: "taloudelliset realistit" eli riippumattomat ja rationaaliset subjektit ovat valkoisia miehiä.

\section{Kunniallisuus vastaan hyödyttömyys}

Edellä kuvaamani näkökulmat talouteen ja siirtolaisuuteen ovat lopulta hyvin samankaltaisia. Puhe romanikerjäläisistä liikkuu enimmäkseen yksilöiden tasolla ja puhe talousromahduksesta enimmäkseen rakenteiden tasolla, mutta kummassakin on pohjimmiltaan kyse siirtolaisten tai tiettyjen etnisten ryhmien suorasta tai välillisestä syyttämisestä. Kolmas havainnoimani näkökulma eli kunniallisuuden ja hyödyttömyyden vastakkainasettelu hieman horjuttaa tätä asetelmaa ja tuo esiin foorumin keskusteluissa vallitsevaa ambivalenssia suhteessa siihen, kuka lopulta kuuluu "meihin" ja kuka ei. Kunniallisuuden ja hyödyttömyyden vastakkainasettelua olen lukenut erityisesti hoitoalalle työhön tulevia siirtolaisia käsittelevästä keskusteluketjusta Maahanmuuttajat ja hoitoala (yhdistetty) $(M H)$ aikavälillä 23.2.2009-22.9.2013 (635 viestiä) ja leipäjonoja käsittelevästä keskusteluketjusta 2012-03-16 Leipäjono kasvaa (LK) aikavälillä 16.3.2012-24.1.2013 (238 viestiä).

Hoitoalaa käsittelevään keskusteluketjuun on yhdistetty useampia eri aikaan käytyjä keskusteluja. Ketjun aloittavat myönteiset kommentit Suomeen työhön saapuvista filippiiniläisistä sairaanhoitajista. Puheenvuorot ovat ratkaisevasti erilaisia verrattuna siihen, mihin tapaan foorumilla yleensä puhutaan siirtolaisista.

Mukavaa että tänne saadaan pari oikeasti työperäistä maahanmuuttajaa. (Nimimerkki CaivsMarivs 23.2.2009, 17:49:26 MH).

Hyvä juttu minusta. Tulkoon vaikka jäädäkseen. Tuota alaa uhkaa kova työvoimapula. (Nimimerkki citizen 19.3.2009, 18:48:12 MH). 
Nämä luonnehdinnat eroavat huomattavasti esimerkiksi myöhemmin samassa ketjussa esitettyihin näkemyksiin espanjalaisista siirtotyöläisistä. Myönteinen suhtautuminen filippiiniläisiin naisiin (hoitoalalle tulevien siirtotyöläisten oletetaan olevan naisia) liittyy ensinnä siihen että heihin liitetään erotisoituja ja rodullistettuja mielikuvia "söpöistä", kilteistä ja ahkerista työntekijöistä jotka "yleensä löytävät kumppanin suomalaismiehestä" (nimimerkki Taustavaikuttaja 20.3.2009, 02:25:33 $M H$ ) ja toiseksi siihen, että filippiiniläisten oletetaan olevan kristittyjä eikä muslimeja.

Minulla ei ole kokemusta filippiiniläisistä hoitajista, mutta jahka niitä tänne tuodaan olen kyllä valmis hoitsuleikkeihin ja tarvittaessa jopa kiihottumaan kansanryhmää vastaan (nimimerkki VMJ, 19.3.2009, 19:12:21 MH).

Itse olen useasti törmännyt filippiiniläisiin suomessa ja joka kerta vaikutelma on vain vahvistunut, ahkeria, ystävällisiä ja vaatimattomia ihmisiä joiden tapaaminen piristää kummasti harmaata päivää. Samaa ei ikävä kyllä voi todellakaan todeta esim. somaleista tai lähi-idän ihmeistä joiden murhaavat ja ylimieliset katseet esim metrossa pilaavat päivän aika tehokkaasti. (Nimimerkki Adrenaline 20.3.2009, 15:45:32 MH).

Filippiiniläiset ovat ahkeria ihmisiä, jotka ovat viettäneet suomessa rauhallista hiljaiseloa ja tehneet töitä. (Nimimerkki Taustavaikuttaja 19.3.2009, 20:36:32 MH).

Tärkein meinasi unohtua. Filippiinit on katolinen maa, joten heillä ei ole ainakaan uskonnollisia ongelmia työtehtäviin. (Nimimerkki kiukiu 19.3.2009, 20:14:03 MH).

On huomionarvoista, että filippiiniläisiä sairaanhoitajia koskevissa puheenvuoroissa mainitaan lukuisia kertoja filippiiniläisille ominaiseksi arveltu ahkeruus, joka tekee heistä monen näkökulmasta toivottuja siirtolaisia. Tätä filippiiniläisten oletettua ahkeruutta vasten asettuu ketjussa hieman yllättäen "kotimaisen reservin työhaluttomuus" (nimimerkki eetos kukkura 24.4.2010, 09:54:27 MH). Alun myönteisten kommenttien jälkeen keskustelu siirtyy varsin nopeasti koskemaan työnantajan mahdollista pyrkimystä 
polkea palkkoja sekä kysymystä siitä onko "hoitajapula" todellinen ilmiö. Tässä kohtaa keskustelussa ilmenee jännitteitä, sillä keskustelijoiden käsitykset "hoitajapulasta" ja sen syistä eroavat. Osassa puheenvuoroista painotetaan, että hoitajien on vaikeaa saada vakituista ja asiallisesti palkattua työtä, mutta osassa taas epäillään, että Suomessa on hoitajapula siksi että "harvalta suomalaiselta löytyy vastaavaa työmoraalia" kuin filippiiniläisiltä sairaanhoitajilta (nimimerkki Leikkimielinen pihapeli 20.5.2010, 01:10:54 $\mathrm{MH})$.

Valitettavasti filippiiniläinen on hyvä työntekijä juuri sen saman aiheen takia kuin suomalainen on "huono". Filippiiniläisellä vaan ei ole kotimaassa kaiken kattavaa sosiaaliturvaverkostoa, kuten meillä. Hämmästyttävän monelle työttömälle riittää se pari iltaolutta ja päivittäinen makaroonilaatikko kunnan vuokrakämpässä aivan(liian) hyvin. Mutta jos nekin viedään, alkaa työntekokin kiinnostaa. (Nimimerkki Porilainen munalla 6.3.2009, 23:58:28 MH).

Tällä tavoin aiemmin analysoimissani ketjuissa varsin säröttömältä näyttänyt jako "meihin" ja "muihin" asettuukin kyseenalaiseksi, sillä osa keskustelijoista on valmis syyttämään suomalaisen terveydenhuollon heikosta tilanteesta myös "kantasuomalaisia" ja leimaamaan heidät(kin) laiskoiksi ja haluttomiksi työhön. Edellisissä luvuissa hahmoteltu jakolinja, jossa taloudellisen rationaalisuuden ja moraaliin liittyvien leimojen avulla määritellään, kuka on ansaitseva ja kuka ansaitsematon, toistuu myös tässä keskustelussa, mutta sukupuoleen ja etnisyyteen liittyvät valtasuhteet asettuvat eri tavalla: suomalaisuus tai valkoisuus ei välttämättä riitäkään perusteluksi ja oikeutukseksi siihen, että kuuluisi "meihin" eli välttyisi syytöksiltä.

Samankaltainen jännite rakentuu myös leipäjonoja käsittelevässä keskusteluketjussa, jossa puheenaiheena on Heikki ja Lahja Hurstin Laupeudentyötä käsittelevä uutinen. Alun perin uutinen lienee lähetetty foorumille, koska siinä mainitaan maahanmuuttajat leipäjonojen "uusimpana ryhmänä". Päinvastoin kuin yleensä foorumilla tässä keskustelussa maahanmuuttajat kuitenkin jäävät sivurooliin ja puheenvuorot käsittelevät enimmäkseen sitä, miksi ihmiset oikeastaan jonottavat leipää ja mitä köyhyys on. Monessa puheenvuorossa Hurstien työtä kehutaan ja kiitellään, mutta joukkoon mahtuu myös toisenlaisia kommentteja, joissa avun tarvitsijoiden oikeutta 
apuun sekä Heikki Hurstin haastattelussa ehdottamaa peruspäivärahan korotusta kyseenalaistetaan:

Kaikki kunnia Heikille, mutta tämmöisissä korotuksissa ei olisi muuta kuin haittaa. Erityisesti työttömyyspäivärahaa pitäisi jonkun verran alentaa, jotta ihmiset viitsisivät hakea töihin. Puolestaan opintotuki on niukka, mutta totta on myös, että monet opiskelijat laittavat opintotukensa ryyppäämiseen. (Nimimerkki John 16.3.2012, 20:57:07 LK)

Jos on työtön niin ei ole onnistunut hankkimaan sellaista tietotaitoa jolle on kysyntää. Karu fakta. Kyseessä on kaupankäynti jossa markkina ostaa osaamistasi, jos tarvittavaa osaamista ei löydy niin sitten sitä joko a) hankitaan lisää tai b) eletään köyhinä. Köyhänä eläminen on vaihtoehto joten en ymmärrä miksi köyhät valittavat. Eric Cartmanin sanoin, stop being so poor... (Nimimerkki Alkuasukas 16.3.2012, 23:36:39 LK).

Jos käyttää ruokarahat viinaan niin sitten on ilman ruokaa. Kyllä sitä pian oppii, ettei se ole fiksua. (Nimimerkki Mursu, 18.3.2012, 15:47:11 $L K)$.

Keskustelusta löytyy kaikuja paitsi uusliberalistisesta "jokainen on oman onnensa seppä" -ajattelusta (Lentin ja Titley 2011, 178; Ong 2006, 11) myös Imogen Tylerin (2008) kuvaamasta "chav"-äiteihin kohdistuvasta moraalisesta paheksunnasta. Eräässä puheenvuorossa todetaan, että "sossurahatilanteeseen joutuessa elämä ei ole ihanaa", mutta epäillään kuitenkin yksinhuoltajien elelevän leveästi yhteiskunnan tuilla:

Jos on joitain, jotka eivät viitsi hakea töitä, he ovat yksinhuoltajat, jotka vastaanottavat kodinhoidontukea, asumistukea, lapsilisiä ja ruokkoja exiltä. Plus sossu, jos ne eivät riitä. Yksinelävä, jos haluaa, voi elää sossurahalla ja siinä ei työttömyyskorvauksen suuruus paina mitään. (Nimimerkki Arvoton 16.3.2012, 21:24:29 LK).

Keskusteluketjussa esitetyt provosoivat kommentit kuten "Ihme elättejä tälläkin palstalla" (nimimerkki Alkuasukas, 18.3.2012, 12:04:48 LK) herättävät myös kiivaita vastareaktioita: "Kuule ala saatana itse yhteiskunnan 
elätiksi jos se sinusta on niin vitun kannattavaa ja hienoa!!” (Nimimerkki retired 17.3.2012, 18:00:54 LK). Keskustelun loppupuolella eräs sivustaseuraaja tiivistää - enemmän tai vähemmän ironisesti - hämmentyneen vaikutelmansa keskustelusta: "Outo ketju! Onko 'Taikaseinä' sittenkin olemassa myös suomalaisille?" (Nimimerkki Pate 23.3.2012, 18:20:19 LK). Tämä kommentti kuvaa hyvin sitä mitä keskustelussa lopulta tapahtuu: tavanomaisesti maahanmuuttajia koskevat argumentit liukuvatkin koskemaan myös osaa "meistä" eli kanssakeskustelijoita, joista monet esittävät omakohtaisia kokemuksia köyhyydestä ja leipäjonoista. Aiemmissa keskusteluissa huolella piirretty raja "meidän" ja muiden välillä osoittautuu tässä - samoin kuin filippiiniläisiä siirtotyöläisiä koskevassa keskustelussa hauraaksi ja huokoiseksi, eikä "meidän" yhtenäisyys enää kannakaan keskinäisenä solidaarisuutena tai kyseenalaistamattomana oikeutuksena "yhteiseen kakkuun".

Tämän säröilyn olen nimennyt vastakkainasetteluksi kunniallisuuden ja hyödyttömyyden välillä, sillä keskustelussa rajaa vedetään yhtälttä moraalisen kunniallisuuden eli ahkeruuden, rehellisyyden ja työteliäisyyden ja toisaalta taloudellisen hyödyttömyyden välille. Moraaliset ja taloudelliset argumentit limittyvät varsin saumattomasti toisiinsa ("laiska" on myös taloudellisesti hyödytön ja "ahkera" hyödyllinen), ja ne ovat itse asiassa samoja, joita aiemmin analysoimissani puhetavoissa viljellään. Erotuksena on ainoastaan se, että tässä kuvaamissani keskusteluissa etnisyyteen, "kulttuuriin" ja uskontoon liittyvien rajanvetojen rinnalla kulkeva taloudellinen ja moraalinen argumentointi nousee näiden rajojen $y l i$ ja alkaakin rikkoa valkoisen nationalistisen projektin kuviteltua yhtenäisyyttä.

\section{Johtopäätökset}

Tässä artikkelissa olen hahmotellut kolme erilaista tapaa, joilla Hommaforumilla puhutaan taloudesta ja talouteen liittyvistä kysymyksistä kuten köyhyydestä. Monet foorumin puheenvuoroista voidaan toki lukea osaksi useampia puhetapoja, joten siinä mielessä tällainen kategorisointi on aina enemmän tai vähemmän keinotekoinen. Tutkimuksen kannalta eri puhetapojen ja niiden kautta rakentuvien näkökulmien erottelu on nähdäkseni kuitenkin mielekästä, sillä samalla piirtyy esiin yhtäältä 
maahanmuuttovastaisen nettikeskustelun sisäistä dynamiikkaa ja ristiriitoja ja toisaalta yhteyksiä valtavirtapolitiikan puheenvuoroihin.

Kuten olen osoittanut, kaikissa talouteen kytkeytyvissä näkökulmissa on viime kädessä kyse taloudellisen rationaliteetin sanelemista rajanvedoista, joissa henkilöiden tai ryhmien oletettu hyödyllisyys tai hyödyttömyys määrittää heidän paikkansa nationalistisessa projektissa eli siinä, millä tavoin Suomea keskusteluissa pyritään rakentamaan ja hallitsemaan. Samankaltaisen havainnon ovat tehneet sekä edellä mainittu Suvi Keskinen (2013b) että Helsingin Sanomien uutisten keskustelupalstoja tutkinut Paula Haara $(2012,66)$ : talouden retoriikka on keskeinen argumentointitapa silloin, kun puhutaan maahanmuuton rajoittamisen puolesta. Merkittävää ei ole ainoastaan se, että hyödyllisyyden retoriikkaa käytetään hyväksi, vaan se että myös uskontoa, "kulttuuria" ja sukupuolta koskevat moraaliset arvostelmat kytkeytyvät erottamattomasti taloudelliseen argumentointiin. Tämän takia mahanmuuttovastaisen keskustelun "totuuksien" haastaminen ei tarkoita ainoastaan rasististen ja sukupuolittuneiden kategorioiden purkamista vaan myös uusliberalistisen logiikan varaan rakentuvan hyödyllisyys/hyödyttömyys-asetelman kyseenalaistamista. Tehtävä on vaikea, sillä tapa hahmottaa siirtolaisuutta ensisijaisesti taloudellisen hyötynäkökulman kautta on, kuten todettua, itse asiassa osa Suomen virallista maahanmuuttopoliittista retoriikkaa.

Kahdessa ensimmäisessä näkökulmassa (köyhyys siirtolaisten syynä ja talousromahduksen odotus) taloudellinen rationaliteetti yhdistyy saumattomasti erilaisiin rodullistettuihin ja sukupuolitettuihin kategorioihin perustuviin moraalisiin arvostelmiin, kun taas kolmannessa näkökulmassa (kunniallisuus vastaan hyödyttömyys) näihin rodullistettuihin ja sukupuolitettuihin kategorioihin perustuva rajanveto säröilee. Tämä ei tarkoita, etteikö kyse edelleen olisi myös etnisyyteen, sukupuoleen ja uskontoon nojaavista erotteluista. Pikemminkin on niin, että taloudelliselle rationaliteetille eli oletetulle hyödyllisyyden ja hyödyttömyyden rajanvedolle rakentuva maahanmuuttokeskustelu ei itsestään selvästi aina sisällä jakoa hyödyllisiin ja ahkeriin "kantasuomalaisiin" ja hyödyttömiin, laiskoihin maahanmuuttajiin - tai ainakaan tätä erottelua eivät kaikki keskustelijat tunnusta. Maahanmuuttovastaisessa keskustelussa rakentuva valkoisten "kantasuomalaisten" miesten kategoria ei näin ollen ole muuttumaton, itsestään selvä tai ongelmaton. 
Keskustelun implisiittisenä järjestäjänä toimiva taloudellinen rationaliteetti tai hyötyajattelu siis toisaalta pönkittää siirtolaisuuteen liittyviä erontekoja ja tukee pyrkimyksiä nationalistiseen hallintaan, mutta samalla se saattaa myös johtaa nationalistisen oikeutuksen kyseenalaistumiseen niiden kohdalla, jotka eivät valkoisuudestaan ja "kantasuomalaisuudestaan" huolimatta onnistu tavoittamaan uusliberalistista ihannetta eli olemaan riittävän hyödyllisiä ja riippumattomia yksilöitä. Tämä kyseenalaistumisen juonne on toki varsin hentoinen verrattuna siihen volyymiin, jolla maahanmuuttovastaisessa nettikeskustelussa jakaudutaan ikään kuin ongelmattomasti "meihin" ja "muihin". Väitän kuitenkin, että juuri tällaiset kyseenalaistumisen ja säröilyn merkit ovat tärkeitä silloin, kun vallitsevia erontekoja pyritään purkamaan ja haastamaan, ja kun mietitään syitä sille, miksi juuri etnisyyteen, uskontoon ja sukupuoleen liittyvät erottelut ovat nykyisen poliittisen keskustelun keskiössä. 


\section{Tutkimusaineisto}

\section{Hommaforum}

Tilastot, haettu 23.9.2013. http://hommaforum.org/index.php?action=stats.

2011-06-26 SK: Mikko Heikka: Suomalaisia köyhiä ajetaan maahanmuuttajia vastaan [Suomalaisia köyhiä] 26.6.2011-28.6.2011, haettu 25.9.2013. http:// hommaforum.org/index.php?topic=52328.0.

Globaali taloustilanne/LAMA! (yhdistetty) [GTL] 25.2.2009-4.6.2013, haettu 12.9.2013. http://hommaforum.org/index.php/topic,2626.0.html.

Öljykriisi, talousrommaus ja energia-asiat (yhdistetty) [ÖTE] 7.8.2009-7.9.2013, haettu 12.9.2013. http://hommaforum.org/index.php/topic,11118.0.html.

Maahanmuuttajat ja hoitoala ( $y$ hdistetty) $(M H)$ 23.2.2009-22.9.2013, haettu 25.9.2013. http://hommaforum.org/index.php/topic,2545.0.html.

2012-03-16 Leipäjono kasvaa (LK) 16.3.2012-24.1.2013, haettu 25.9.2013. http:// hommaforum.org/index.php?topic=68871.0.

\section{Taustahaastattelut}

Taustahaastattelu 1. Homman moderaattori. 20.11.2012 Helsinki.

Taustahaastattelu 2. Homman aiempi rekisteröitynyt aktiivikirjoittaja. 1.4.2013 Tampere.

Taustahaastattelu 3. Homman nykyinen rekisteröitynyt kirjoittaja. 28.-30.5.2013 sähköpostihaastattelu.

\section{Muut}

Heikka, Mikko. 2011. Suomalaisia köyhiä ajetaan maahanmuuttajia vastaan. Suomen Kuvalehti, haettu 25.9.2013. http://suomenkuvalehti.fi/blogit/ eri-mielta/mikko-heikka-suomalaisia-koyhia-ajetaan-maahanmuuttajiavastaan. 


\section{Kirjallisuus}

Julkaisemattomat lähteet

Keskinen, Suvi. 2013b. Työryhmäesitelmä Nordic Populism -verkoston seminaarissa Turussa 21.5.2013.

\section{Julkaistut lähteet}

Atton, Chris. 2006. Far-right media on the internet: culture, discourse and power. New Media Society 8(4), 573-587.

Betz, Hans-Georg ja Johnson, Carol. 2004. Against the current - stemming the tide: the nostalgic ideology of the contemporary radical populist right. Journal of Political Ideologies 9(3), 311-327.

Förbom, Jussi. 2010. Hallan vaara. Merkintöjä maahanmuuton puhetavoista. Helsinki: Into Kustannus.

Haara, Paula. 2012. Poliittinen maahanmuuttokeskustelu Helsingin Sanomien verkkokeskustelussa. Teoksessa Mari Maasilta (toim.), Maahanmuиtto, media ja eduskuntavaalit. Tampere: Tampere University Press, 52-86.

Hage, Ghassan. 2000. White nation. Fantasies of white supremacy in a multicultural society. New York: Routledge (in association with Pluto Press).

Hage, Ghassan. 2003. Against paranoid nationalism. Searching for hope in a shrinking society. Annandale: Pluto Press Australia.

Horsti, Karina. 2005. Vierauden rajat. Monikulttuurisuus ja turvapaikanhakijat journalismissa. Tampere: Tampere University Press.

Isomäki, Hannakaisa, Lappi, Tiina-Riitta ja Silvennoinen, Johanna. 2013. Verkon etnografinen tutkimus. Teoksessa Laaksonen, Salla-Maaria, Matikainen, Janne \& Tikka, Minttu (toim.), Otteita verkosta. Verkon ja sosiaalisen median tutkimusmenetelmät. Tampere: Vastapaino, 150-169.

Keskinen, Suvi. 2009. Pelkkiä ongelmia? Maahanmuutto poliittisen keskustelun kohteena. Teoksessa Suvi Keskinen, Anna Rastas ja Salla Tuori (toim.) En ole rasisti mutta... maahanmuutosta, monikulttuurisuudesta ja kritiikistä. Tampere: 
Vastapaino, 33-46.

Keskinen, Suvi. 2012. Sananvapauden vaatimuksia ja rodullistavaa puhetta tanskalaisen ja suomalaisen maahanmuuttokeskustelun risteyskohtia. Oikeus 2(2012), 287-294.

Keskinen, Suvi. 2013a. Antifeminism and White Identity Politics - Political Antagonisms in Radical Right-wing Populist and Anti-immigration Rhetoric in Finland. Nordic Journal of Migration Research 0(0), 1-8. DOI: 10.2478/njmr2013-0015, November 2013.

Koivulaakso, Dan, Brunila, Mikael ja Andersson, Li. 2012. Ä̈̈rioikeisto Suomessa. Helsinki: Into Kustannus.

Laaksonen, Salla-Maaria, Matikainen, Janne ja Tikka, Minttu. 2013. Tutkimusotteita verkosta. Teoksessa Laaksonen, Salla-Maaria, Matikainen, Janne \& Tikka, Minttu (toim.), Otteita verkosta. Verkon ja sosiaalisen median tutkimusmenetelmät. Tampere: Vastapaino, 9-33.

Lentin, Alana. 2005. Replacing 'race', historicizing 'culture' in multiculturalism. Patterns of Prejudice 39(4), 379-396.

Lentin, Alana ja Titley, Gavan. 2011. The crises of multiculturalism. Racism in a neoliberal age. London \& New York: Zed Books.

Maasilta, Mari. 2012a. Johdanto. Teoksessa Mari Maasilta (toim.), Maahanmuutto, media ja eduskuntavaalit. Tampere: Tampere University Press, 7-22.

Maasilta, Mari. 2012b. Epilogi. Teoksessa Mari Maasilta (toim.), Maahanmuutto, media ja eduskuntavaalit. Tampere: Tampere University Press, 159-162.

Nordberg, Camilla. 2010. Tutut vieraat - Suomen romanit, työelämän marginaalissa? Teoksessa Sirpa Wrede ja Camilla Nordberg (toim.), Vieraita työssä. Työelämän etnistyvä eriarvoisuus. Helsinki: Helsinki University Press, 254-273.

Ong, Aihwa. 2006. Neoliberalism as exception. Mutations in citizenship and sovereignty. Durham ja London: Duke University Press.

Pitcher, Ben. 2012. Race and capitalism redux. Patterns of Prejudice 46(1), 1-15, DOI: 10. 1080/0031322X.2012.655524. 
Shildrick, Tracy ja MacDonald, Robert. 2013. Poverty talk: how people experiencing poverty deny their poverty and why they blame 'the poor'. The Sociological Review 61(2013), 285-303.

Skeggs, Beverley. 1997. Formations of Class and Gender. Becoming Respectable. London, Thousand Oakes ja New Delhi: SAGE Publications.

Skeggs, Beverley. 2004. Class, Self, Culture. London: Routledge.

Turtiainen, Riikka ja Östman, Sari. 2013. Verkkotutkimuksen eettiset haasteet: Armi ja anoreksia. Teoksessa Laaksonen, Salla-Maaria, Matikainen, Janne \& Tikka, Minttu (toim.), Otteita verkosta. Verkon ja sosiaalisen median tutkimusmenetelmät. Tampere: Vastapaino, 49-67.

Tyler, Imogen. 2008. "CHAV MUM CHAV SCUM". Class disgust in contemporary Britain. Feminist Media Studies 8(1), 17-34.

\section{Viitteet}

I) Aineistoni ja tutkimusmenetelmien rajallisuuden takia tässä artikkelissa ei ole mahdollista tehdä yleistyksiä koskien sitä, millä kaikilla tavoin taloudesta Hommaforumilla puhutaan - kyse on siis ennemminkin siitä, että ainakin seuraavanlaisia puheen muotoja foorumilta löytyy.

2) Hommaforumille on tyypillistä omien sanojen ja ilmaisujen kehittäminen sekä omien merkitysten rakentaminen jo olemassa oleville sanoille - tätä tarkoitin edellä viitatessani kielipoliittiseen peliin. Osa näistä sanoista ja sanonnoista on myös lyönyt läpi valtavirran julkiseen keskusteluun, jolloin niiden poliittinen tarkoitushakuisuus helposti peittyy näkyvistä ("maahanmuuttokriittisyys" on tästä hyvä esimerkki). Tämän artikkelin raameissa ei ole mahdollista analysoida kovin pitkälti Hommaforumilla käytettyjä sanontoja ja niiden ongelmallisuutta, mutta viestiksi siitä että kyseessä on nimenomaan poliittisesti tarkoitushakuinen ilmaus laitan näiden sanojen ympärille lainausmerkit. 